University of Nebraska - Lincoln

DigitalCommons@University of Nebraska - Lincoln

Faculty Publications, Department of History

History, Department of

2020

\title{
From Student to Citizen: The Impact of Personal Narratives in University-Level Genocide Education
}

\author{
Ari Kohen \\ University of Nebraska-Lincoln, akohen2@unl.edu \\ Gerald Steinacher \\ University of Nebraska-Lincoln, gsteinacher2@unl.edu
}

Follow this and additional works at: https://digitalcommons.unl.edu/historyfacpub

Part of the Curriculum and Instruction Commons, Educational Methods Commons, European History Commons, Higher Education Commons, Holocaust and Genocide Studies Commons, and the Humane Education Commons

Kohen, Ari and Steinacher, Gerald, "From Student to Citizen: The Impact of Personal Narratives in University-Level Genocide Education" (2020). Faculty Publications, Department of History. 233. https://digitalcommons.unl.edu/historyfacpub/233

This Article is brought to you for free and open access by the History, Department of at DigitalCommons@University of Nebraska - Lincoln. It has been accepted for inclusion in Faculty Publications, Department of History by an authorized administrator of DigitalCommons@University of Nebraska - Lincoln. 


\title{
From Student to Citizen: The Impact of Personal Narratives in University-Level Genocide Education
}

\author{
Ari Kohen \\ Schlesinger Associate Professor of Political Science and \\ Director of the Forsythe Family Program on Human Rights and Humanitarian Affairs, \\ University of Nebraska-Lincoln \\ Gerald J. Steinacher \\ Professor of History and Hymen Rosenberg Professor of Judaic Studies, \\ University of Nebraska-Lincoln
}

\section{Introduction}

It has long been assumed that courses on the Holocaust and other genocides can instill important lessons in students rather than simply teaching facts about history. As former UN secretary-general Kofi Annan (2010) writes:

Many countries in Europe and North America now require all high-school pupils to learn about the Holocaust. Why? Because of its historical importance, of course, but also because, in our increasingly diverse and globalized world, educators and policy-makers believe Holocaust education is a vital mechanism for teaching students to value democracy and human rights, and encouraging them to oppose racism and promote tolerance in their own societies. (p. 1)

Published as Chapter 16 in Teaching about Genocide: Advice and Suggestions from Professors, High School Teachers, and Staff Developers. Volume 3. Edited by Samuel Totten. Published by Rowman \& Littlefield.

Copyright (c) 2020 Samuel Totten. Used by permission.

doi: 10.32873/unl.dc.oth.oog 
This is a fine belief, but is there any evidence that students who study the Holocaust become more concerned about human rights and social justice, generally, or even specifically about antisemitism and xenophobia? And how can the case of the Holocaust promote empathy, compassion, and humanitarian understanding more broadly? Annan (2010) explains,

If our goal in teaching students about the Holocaust is to make them think harder about civic responsibility, human rights and the dangers of racism, then presumably we need to connect the Holocaust with other instances of genocide, and with ethnic conflicts or tensions in our own time and place. That would enable students not only to learn about the Holocaust, but also to learn important lessons from it. (p. 1)

What follows, then, are some of the lessons gleaned from the first ever long-term, multi-phase, interpretative case study conducted in higher education; a complete exploration and analysis of the data collected in the project is beyond the scope of this short essay. Using more than one thousand surveys, in-person interviews, and other evaluative materials gathered over the course of five years, our research team sought answers to the questions posed above and looked specifically at the ways in which certain types of instructional materials make impressions on students.

What is argued here is that narrative sources such as autobiographies, diaries, letters, and interviews, as well as engagement with eyewitnesses, help to foster in students a deeper, more personal connection to the experiences of genocide victims as well as those of bystanders, rescuers, and perhaps even perpetrators.

The hypothesis was based mostly on anecdotal evidence because no existing study focused specifically on whether or not a connection exists between formal university-level genocide education through primary sources and a deeper impact beyond just factual learning.

Although postsecondary education has always been about more than just knowledge- and skill-building, the need to promote engaged citizenship among young people is especially pressing now, as hate crimes in the United States are on the rise and democracies all over the globe are in peril. 
The sharp uptick in antisemitism, xenophobia, and scapegoating of ethnic or religious minorities shows the urgency and practical application of this research study. It is hoped that by encouraging student engagement, young people are not solely to avoid being bystanders but to actively engage in the prevention of hatred and violence.

\section{The class}

At the University of Nebraska-Lincoln, the Holocaust is taught as an upper-level history course, but it is open to all students with sophomore standing without any prerequisite courses; in addition, it fulfills an important general education requirement for students across the university. The students come from various disciplines and fields, most notably journalism, history, business, political science, psychology, and global studies.

This is a dynamic class, with the professor's classroom lectures being just one element among many. Every semester at least four guest speakers come to the class, including experts on the Rwandan and Armenian genocides. In addition, the class hosts two to three Holocaust survivors over the course of the semester. At the conclusion, the class takes a field trip to a local synagogue or the site of a Holocaust memorial.

Students are also invited to attend events outside the classroom, such as movies or public talks, which are announced in class and online. Attending such events is not required, and students generally do not receive extra credit for doing so.

Together with teaching assistants, the professor screens relevant films in the evening, followed by discussions and study sessions just before exams. Clearly, coordinating and managing all these elements requires enormous effort.

The main required readings for the course are: Doris Bergen's (2002) War and Genocide, Christopher Browning's (2017) Ordinary Men, Simon Wiesenthal's (1997) The Sunflower, Primo Levi's (2012) Survival in Auschwitz, and Elie Wiesel's (2020/1956) Night.

During the course of the semester, students watch the films Nazi Medicine (Eugenics) (Michalczyk, 2003), Night and Fog (Resnais, 2016), A Film Unfinished (Hersonski, 2010), and Hitler's Children 
(Ze'evi, 2011), as well as clips from the Milgram experiment and various pieces of original footage from the 1930 s and 1940s (e.g., scenes from Triumph of the Will [Riefenstahl, 2001] and the Olympic Games of 1936).

In addition, students are shown a large number of short interviews with Holocaust survivors from the USHMM website (e.g., in the context of the 1938 Pogrom). Two weeks of class time are dedicated to the history of antisemitism. The class also includes teaching about other genocides like the Armenian or Rwandan, as well as cases of mass violence and massive war crimes committed in Ethiopia (1935/1941) and China (e.g., Nanking).

On average, more than 130 students enroll in the class each year, providing our study with a large data sample representative of a crosssection of students with diverse personal and professional interests and goals. A small number of students with a Jewish background as well as some students from the university's human rights and humanitarian affairs minor also tend to enroll.

Indeed, students with majors unrelated to history, human rights, or other related subjects are often more willing to take a course on a topic about which they already have at least some knowledge, such as the Holocaust, than on a topic about which they know very little or next to nothing (for example, the Armenian genocide).

\section{Research design}

This study set out to determine whether there is a causal connection between a course curriculum that includes more personal narrative materials (as opposed to general historical texts) and increased student empathy, understanding, and engagement with topics and activities broadly related to social justice and human rights.

If it is true that educators can spark and nurture student interest in social justice and human rights, then students might well become more caring, empathetic, and engaged citizens. To test the hypothesis, an interdisciplinary research team of faculty and students was created to carry out a long-term, multi-phase interpretative case study. Survey responses, interviews, course evaluations, diaries, and the like were collected and analyzed annually for five years. 
During the initial course meeting, without the instructor present, the co-principal investigator (co-PI) who was not involved in the course introduced the students to the research project, answered questions, handed out and collected informed consent forms, and then passed out surveys, provided students with time to answer survey questions, and then collected the survey forms.

This process, minus the consent forms, was completed a second time during the final week of classes. The co-PI was assisted by members of the research team, which consisted of graduate and undergraduate students who were not involved in the course in any other capacity.

During the initial class meeting each year, students were told that a random group would be contacted and asked to participate in two semi-structured interviews or focus group meetings during the course of the semester; they were informed that their participation was entirely voluntary. Students were always informed that their instructor would not know whether or not they participated and their participation-or lack thereof-would have no impact on their grade for the course.

Only the members of the research team had access to these individual audio and video recordings for the purpose of transcription. All data were obtained specifically for research purposes and kept in a locked file cabinet in the co-PI's campus office. Coding of survey data was conducted by members of the research team, cross-checked by other members of the team, and then interpreted together with the co-PI.

Over the course of five years, the research team gathered data from a total of some 550 students, each of whom completed pre- and postclass surveys. In addition, the team conducted in-depth interviews with more than a dozen students and solicited feedback through anonymous written student evaluations.

This amounted to a great deal of raw data whose findings confirmed the hypothesis: Students who read first-hand accounts of Holocaust and genocide survivors-for example, Wiesenthal's The Sunfloweras well as watching video interviews and having direct interactions with Holocaust survivors were more deeply engaged in that material and were more apt to engage others about the topic outside of the classroom. 


\section{Measuring student engagement}

The definition of engagement employed in this study (which coincides with what is widely accepted by the learning community) goes beyond simple changes in observed or reported behavior. The authors acknowledge that engagement is a construct that is multifaceted, with emotional and cognitive aspects, and can manifest itself in many ways.

Moreover, the authors do not contend that the causal arrow goes only from learning to engagement and not the other way around, or that there will always be a relationship between the two. A student might learn a lot about a topic without caring about it one bit, and vice versa. There is a meaningful distinction to be made between a student who is simply performance-oriented and one who is truly learning-oriented.

What this study investigates is whether or not the materials assigned in courses can increase the likelihood of student engagement and bridge the gap that often exists between learning facts and internalizing the lessons being conveyed.

Because engagement is multifaceted, it is therefore difficult to measure. In an attempt to optimize the learning environment and outcomes of college-level mathematics and psychology courses, Mitchell Handelsman and his colleagues at the University of Denver (2005) set out to create a reliable measure of student engagement and designed what is known as the Student Course Engagement Questionnaire (SCEQ) to solicit responses on twenty-seven indicators-attitudes and behaviors-of engagement.

The SCEQ has students rank the indicators according to how strongly they feel their classes elicited in them those attitudes and behaviors. The information gathered from students about their learning experience can reveal what, if any, impact a course had upon them as well as any corresponding effects that the materials selected by an instructor might have had on their beliefs and actions. This study bases its questionnaire on the SCEQ.

Although the Holocaust is widely taught and relates directly to the themes of social justice and human rights, existing research has yet to address how best to present this information in order to make a lasting impact on students and to encourage engagement. In an extensive literature review on moral education, Jaap Schuitema, Geert 
ten Dam, and Wiel Veugelers (2008) found that the variety of objectives and outcomes in empirical research on moral education makes it difficult to compare studies' outcomes or effectiveness (pp. 6o-89).

Schuitema and colleagues' (2008) review mentions only one study focusing on Holocaust education as a vehicle for moral education, but that study's authors did not detail their instructional design (p. 12). The students who participated in the study reported "that the lessons had increased their awareness of racism," but "when they were asked to elaborate on the concepts of 'stereotyping' and 'scapegoating' ... they did not show a deep understanding of these concepts."

Our own later review of the existing literature on Holocaust education and courses with social justice themes led us to agree with Schuitema and colleagues (2008), who concluded that there is "relatively little empirical research on the effectiveness of teaching strategies for moral education" (p. 12).

Joseph Braun and Stephen Arves (2014) have studied human rights campaigns, asking whether reading text, looking at visual imagery, or some combination thereof is most effective in spurring action. They consider various assertions about the impact of first-person narrative texts and of images (e.g., photos of tortured prisoners at Abu Ghraib) on individual attitudes toward human rights abuses and argue that, while "there have been no attempts to systematically investigate the claim that written narratives move individuals to recognize the rights of other persons," there are empirical studies showing the powerful, long-lasting effects of visual imagery (Braun \& Arves, 2014, p. 4).

Lynn Hunt (2011) writes, "It is a truism that photography, in particular, played and still plays a major role in human rights campaigns" ( $p$. xi). The outcomes of such studies often differ, however, and are more complicated than they seem. This is in part because seeing and understanding are not the same things and do not always go hand in hand.

Braun and Arves's (2014) findings support our hypothesis that a Holocaust or genocide history class using mostly materials centered around personal narratives, as opposed to general historical texts, should do better in terms of engaging students, thereby establishing greater levels of care about social justice and human rights along with a willingness to act on behalf of others (p. 10).

Braun and Arves's study is perhaps the most central to our theory, in no small part because it serves as a broad test of the philosopher 
Richard Rorty's (1989) interesting but extremely underdeveloped theory that solidarity and empathy result directly from personal identification (p. 191).

Michael Dahlstrom (2014) has stressed the effectiveness of narrative storytelling as a way to communicate science to non-expert audiences (p. 13614). It follows that a Holocaust or genocide history course taught using narrative material, including diaries and testimonies, has a greater chance of engaging not only students who already know about the Holocaust but also those who neither know nor care specifically about the Holocaust, genocide, or human rights.

If personal narratives are as effective at getting people to truly care about human rights issues as contemporary research shows, then this sort of curriculum should foster engagement-to an extent that a curriculum consisting entirely of general historical texts does not.

\section{Results}

Education, especially at the post-secondary level, should serve as a transformative experience that teaches students to think critically about the world around them. Altering the way information is presented-favoring personal narratives over textbooks-can help to apply learned concepts to real life, motivate students to become involved in human rights causes, and to seek out additional courses related to human rights and social justice. To achieve this goal, faculty often take an "applied learning" approach, situating classroom learning within real-world contexts.

This practical approach focuses on applying lessons from the course to actual situations or circumstances that could be encountered in the world. A course about the Holocaust or other genocides designed along these lines should generate a desire among students to "get involved" on behalf of others by eliciting strong emotional reactions, fostering empathy, and creating a more personal connection to victims of human rights abuses.

These ideas are borne out in the results of this study. A majority of the 550 students surveyed said they discussed course material outside the classroom; some attended lectures and presentations on topics related to human rights during the semester; others asked for ex- 
tra readings and assignments; and nearly half said they planned to keep all the books after the course concluded.

Finally, and perhaps most tellingly, when participants were asked whether what they learned in the course could be applied to their life, work, or other courses, more than 70 percent agreed or strongly agreed.

Not all the results are so clear-cut, however. A look at the surveys and other materials gathered over the five-year period gives a more complete picture. The pre- and post-surveys, interviews, and other feedback clearly show that students feel they learned a lot from the class. They often express surprise at the richness and depth of what they learned over the course of the semester.

Students particularly point out a better or completely new understanding of the long history of antisemitism, the widespread knowledge of atrocities and persecution at the time (e.g., in the United States), the history of eugenics and Nazi euthanasia, and Jewish resistance (e.g., the Warsaw Ghetto uprising). One student in the 2016 class wrote a very representative answer:

I grew up being told that: 1 . The German people were brainwashed by Hitler; didn't know of/couldn't understand the Holocaust. 2. The rest of the world didn't know about the Holocaust. 3. The Nazis were evil/inhuman etc.

I learned that: 1. Propaganda was only a small factor; most Germans knew what was happening, to some degree (and were OK with it without "brainwashing"). 2. The world knew, and was silent. 3. The Nazis were just people. 4. We are all capable of committing evil acts.

This study also shows that students' perceptions changed strongly with regard to bystanders and perpetrators, who came to be seen more as ordinary people than as unknowable "monsters." Students stated again and again that Ordinary Men and documentaries like Hitler's Children challenged their beliefs.

The students engaged more, had greater empathy, and were inspired by classroom materials such as The Sunflower to ask questions, often deep ones, about guilt, responsibility, and forgiveness. Perhaps it is because most students have not been confronted with such issues 
and questions before coming to a Holocaust history class that texts like The Sunflower make such a deep impact on them, as the many surveys clearly show.

In every year that was analyzed, students chose Simon Wiesenthal's The Sunflower as the book that most resonated with them. Survey data shows that, of the students who planned to keep their books, 48.5 percent said they were keeping "all books" from the course.

The Sunflower was the most popular response after "all books" and was always the most popular book among the students. In fact, of the students who were planning to keep some of the texts but not all of them, 73.3 percent planned on keeping The Sunflower, and more than half of those students planned to keep only that book (53.3 percent).

Course evaluations also revealed that 54 percent of students specifically mentioned it as a book that they enjoyed. In 2013, students were surveyed at the end of the semester about whether or not they found themselves talking to friends, family members, roommates, or others about this course in particular. The responses show that nearly all students did talk to friends or family about the course (93.8 percent), while only 6.2 percent reported not having discussed it outside of class.

These findings indicate that certain types of classroom materials make a stronger impact on student learning and behavior than others. In short, the use of primary sources seems to increase student interest and improve learning outcomes. Over the course of a semester, students become even more interested in the topic of the Holocaust and leave with a very different understanding than they originally had.

This in itself is an important outcome, especially considering that common knowledge about the Holocaust is sketchy even in educated circles. The broader or more enduring impact of university-level Holocaust teaching on ethics and activism, however, is clearly more difficult to clearly show.

While the data bears out the authors' hypothesis in interesting ways, it is nonetheless important to note that we have only a fifteenweek time period in which to impart lessons to students and in which we can collect data.

A longer course might have outcomes that are more easily measured, but most students don't enroll in courses that cover Holocaust or genocide studies across multiple semesters, nor were we able to 
measure whether or not students enrolled in courses that examined other genocides.

Furthermore, of course, the possible long-term impact of the intervention was not assessed here; thus there is no data, apart from the anecdotal, about the impact this course might have had on students years into the future.

Hundreds of students were impacted in important ways by the study of personal narratives relating to the Holocaust; more than one thousand surveys and a large body of additional feedback from interviews and evaluations make it clear that there were measurable short-term impacts.

Though it would require a great deal of resources and though the response rate undoubtedly would be lower than that of an inclass survey, expanding the study to include the reflections of alumni would amplify the results of this path-breaking research in Holocaust education.

\section{References}

Annan, Kofi (2010). “The Myth of 'Never Again.” The New York Times (June 17), p. Opinion, p. 1.

Bergen, D. L. (2002). War and genocide: A concise history of the Holocaust. Rowman \& Littlefield.

Braun, Joseph, and Arves, Stephen (2014). "See No Evil, Read No Evil: Measuring the Effects of Imagery and Narrative on Human Rights Attitudes." American Political Science Association Annual Meeting Paper. Accessed at: https:// papers.ssrn.com/s013/papers.cfm?abstract id $=2453038$

Browning, C. R. (2017). Ordinary men: Reserve Police Battalion 101 and the final solution in Poland. Harpercollins.

Dahlstrom, Michael F. (2014). "Using Narratives and Storytelling to Communicate Science with Nonexpert Audiences." Proceedings of the National Academy of Sciences of the United States of America, 111, Supplement 4, 13614-13620.

Handelsman, M. M.; Briggs, W. L.; Sullivan, N., and Towler, A. (2005). "A Measure of College Student Course Engagement.” Journal of Educational Research, 93(3), 184-191.

Hersonski, Y. (2010). A film unfinished [film]. Oscilloscope Pictures.

Hunt, Lynn (2011). "Foreword," pp. ix-xii. In Sharon Sliwinski's Human Rights in Camera. University of Chicago Press.

Levi, P. (2012). Survival in Auschwitz: The Nazi assault on humanity. Important Books. 
Michalczyk, J. J. (2003). Nazi medicine: The cross and the star [film]. First Run Features.

Resnais, A. (2016). Night and fog [film]. The Criterion Collection.

Riefenstahl, L. (2001). Triumph of the will [film]. Synapse Films.

Rorty, Richard (1989). Contingency, Irony, and Solidarity. Cambridge University Press.

Schuitema, J.A.; ten Dam, G.; and Veugelers, W. (2008). "Teaching Strategies for a Moral Education: A Review." Journal of Curriculum Studies, 40(1), 69-89.

Wiesel, E. (2020). Night. Thorndike Press. (Original work published 1956)

Wiesenthal, S. (1997). The sunflower: On the possibility and limits of forgiveness. Schocken Books.

Ze'evi, C. (2011). Hitler's children [film]. Kanopy Streaming. 